\title{
What is known about palliative care in adult patients with allogeneic stem cell transplantation (allo-SCT)?
}

\author{
Steffen T. Simon ${ }^{1,2,3} \cdot$ Anne Pralong ${ }^{1,2}$ (I) $\cdot$ Michael Hallek ${ }^{2,4} \cdot$ Christoph Scheid $^{2,4} \cdot$ Udo Holtick $^{2,4} \cdot$ Marco Herling $^{2,4,5}$
}

Received: 23 December 2020 / Accepted: 19 April 2021 / Published online: 6 May 2021

(C) The Author(s) 2021

\begin{abstract}
Patients undergoing allogeneic stem cell transplantation (allo-SCT) are given a real chance of cure, but at the same time are confronted with a considerable risk of mortality and of severe long-term impediments. This narrative, non-systematic literature review aims to describe the supportive and palliative care needs of allo-SCT recipients, including long-term survivors or those relapsing or dying after transplantation. It also evaluates the feasibility and effectivity of integrating palliative care early in transplant procedures. In this appraisal of available literature, the main findings relate to symptoms like fatigue and psychological distress, which appear to be very common in the whole allo-SCT trajectory and might even persist many years post-transplantation. Chronic GvHD has a major negative impact on quality of life. Overall, there is a paucity of research on further issues in the context of allo-SCT, like the distress related to the frequently unpredictable post-transplant trajectory and prognosis, as well as the end-of-life phase. First randomized controlled results support the effectiveness of early integration of specialized palliative care expertise into transplant algorithms. Barriers to this implementation are discussed.
\end{abstract}

Keywords Stem cell transplantation · Allogeneic transplantation $\cdot$ Quality of life $\cdot$ Palliative medicine $\cdot$ Supportive care

\section{Introduction}

The long-term survival after allogeneic hematopoietic stem cell transplantation (allo-SCT) has been increasing, which is mostly attributable to continuous advancements in procedural aspects and supportive measures [1-3]. Despite these

Steffen T. Simon and Anne Pralong contributed equally to this work.

Anne Pralong

anne.pralong@uk-koeln.de

1 Faculty of Medicine and Cologne University Hospital, Department of Palliative Medicine, University of Cologne, 50924 Cologne, Germany

2 Faculty of Medicine and Cologne University Hospital, Center for Integrated Oncology Aachen-Bonn-Cologne-Duesseldorf (CIO ABCD), University of Cologne, Cologne, Germany

3 Faculty of Medicine and Cologne University Hospital, Center for Health Services Research (ZVFK), University of Cologne, Cologne, Germany

4 Faculty of Medicine and Cologne University Hospital, Department of Internal Medicine I, University of Cologne, Cologne, Germany

5 Clinic of Hematology and Cellular Therapy, University of Leipzig, Leipzig, Germany improvements, the overall mortality associated with alloSCT remains high. The 5-year survival after allo-SCT, all diagnoses included, is about 50\% [4]. Complications of the allo-SCT often lead to severe symptomatology, requiring optimal supportive and palliative management.

Palliative care aims to improve "the quality of life of patients and their families facing the problem associated with life-threatening illness, through the prevention and relief of suffering by means of early identification and impeccable assessment and treatment of pain and other problems, physical, psychosocial and spiritual" [5]. Relieving symptoms and managing other causes of suffering in cancer patients is mainly the task of oncologists and primary care teams in the sense of primary palliative care, but in complex situations, involvement of specific palliative care expertise will be necessary [6-8]. The early integration of such specialist palliative care into concepts of cancer therapy has become integral part of standard cancer care as recommended in several oncology and palliative care guidelines [6, 8-11]. Mounting evidence attests the effectiveness of early specialist palliative care in patients with solid tumors in the control of symptom intensity and with positive impacts on quality of life $[6,8,9,12,13]$.

In contrast to solid cancers, specialist palliative care services are less frequently used in patients with hematological 
malignancies [14]. These patients receive more invasive therapies, even until shortly before death and are less likely to be informed about near death [14-16]. These facts from clinical practice are reflected in the current state of research in this area. There are few prospective studies that investigated the effect of early-integrated palliative care into the therapeutic algorithms in hematology $[17,18]$, in particular in allo-SCT [19], although recent results from randomized controlled trials indicate growing interest and research activity in that field [20-22].

Particularly recipients and survivors of an allo-SCT deserve special attention, because of the high morbidity and mortality associated with this modality. There is a high need to best identify and manage the many unmet needs in the field of supportive and palliative care during the whole transplant trajectory. In this non-systematic review, we aim to provide an overview on the current literature and state of the art on supportive and palliative care in patients with allo-SCT, which includes (1) symptoms, psychosocial distress, quality of life, burden related to the unpredictable illness trajectory and prognosis, issues in the last phase of life, support of family caregivers and (2) the integration of specialist palliative care services into transplant algorithms. For this purpose, we conducted a non-systematic search in the database MEDLINE (via PubMed), combining search terms on allo-SCT and on palliative care, psycho-oncology, uncertainty, fear of recurrence, or death anxiety. Further publications were identified by cross-referencing from publications listed in relevant studies and by citation tracking via the PubMed link for "related articles." We included (systematic) reviews as well as original research articles (presented in Table 1). We considered studies including adult patients having undergone allo-SCT and/or their informal caregivers. Reviews or primary studies on hematology or SCT in general were also included if they reported specific results on allo-SCT. Primary studies with more than two-thirds of allo-SCT participants were considered as well. In this review, we also highlight relevant research gaps.

\section{Symptoms, psychosocial distress, and quality of life}

The impact of allo-SCT on symptoms and quality of life has been the topic of numerous reviews [19, 52-64] and more recent primary studies (see Table 1 ). The most prevalent physical symptoms in the first 3 months after allo-SCT are fatigue, sleep disturbances, nausea, lack of appetite, and indigestion (obstipation or diarrhea) $[27,32,56]$. Their incidences peak during the period from transplantation until 1 month thereafter $[27,32]$. At about 1 month, physical symptoms start to decrease and physical functions noticeably improve [24, 32, 59] and tend to reach baseline levels at about 1 year posttransplantation $[24,59]$. Overall, allo-SCT recipients after a myeloablative conditioning seem to show more symptoms and a slower recovery than those with reduced-intensity conditioning (RIC) [24, 32, 57].

Symptoms, which persist at least 1 year after allo-SCT compared with population norms and non-cancer comparison groups, include fatigue, sleeping disorders, pain, and sexual dysfunction $[28,53,56]$, with fatigue being associated with female gender and younger age, as well as acute and chronic GvHD [37, 54]. In a prospective multicenter study with 239 patients, fatigue was identified as the most persistent and severe symptom even 5 years after allo-SCT; it was also the most important predictor of a reduced quality of life [38]. Even if global fatigue returned to pre-transplantation levels after about 1 year and remained stable for the next 5 years, it was still significantly more prevalent than in the general population [37].

Patients with acute graft-versus-host disease (GvHD) have a higher burden of physical symptoms and inferior physical well-being [32, 50]. Chronic GvHD is an important issue at long term and predicts very strongly the persistence of impaired physical functions [28, 54, 57].

Psychological distress is among the most prevalent symptoms in patients with allo-SCT [52-54]. Anxiety has been described as frequently increased especially before transplantation [40], while depression becomes prominent post-transplantation, with an increased prevalence until 10 years postallo-SCT [40, 54]. Post-traumatic stress disorders (PTSD) is a major concern in about 5 to $19 \%$ of SCT survivors, independent of the kind of transplantation [21, 39, 54, 65]. Cognitive disorders are relatively common among patients that undergo and underwent an allo-SCT, and are frequent even before the transplantation [48, 49]. A cognitive decline from pre- to post-(allo-)SCT could not be demonstrated in a metaanalysis of 404 patients [58]. Compared to autologous SCT recipients, patients with allo-SCT appear to have a higher risk for long-term psychological distress, especially those with chronic GvHD [52, 54]. Acute and chronic GvHD both have a negative impact on mental health $[50,59]$.

The quality of life after transplantation has been reported to return to pre-allo-SCT levels after about 1 year [50, 54, 59]. Risk factors for poorer quality of life include young age, female gender, low educational level, limited social support, physical symptoms, and depression as well as acute and chronic GvHD [54]. Chronic GvHD is the major cause of impaired quality of life in allo-SCT survivors [55]. Patients with poorer quality of life have a higher risk of expressing regrets about their decision to undergo the allo-SCT procedure [33].

The effectiveness of early integration of specialist palliative care on symptom burden, psychological distress, and quality of life was examined in a randomized controlled trial (RCT) with 160 SCT recipients - to our knowledge the only one to date in the context of SCT $[20,21]$. The interventional group 
Table 1 Primary studies identified by the PubMed search on palliative and supportive care needs in allo-SCT recipients and on specialist palliative care integration

\begin{tabular}{llll}
\hline $\begin{array}{l}\text { First author, year, } \\
\text { country }\end{array}$ & Study design & Patient population & Main outcomes
\end{tabular}

\begin{tabular}{|c|c|c|c|}
\hline $\begin{array}{l}\text { Amonoo } 2019 \text { [23], } \\
\text { USA }\end{array}$ & $\begin{array}{l}\text { Sequential } \\
\text { qualitative } \\
\text { interviews }\end{array}$ & $\begin{array}{l}25 \text { allo-SCT recipients at } \\
\text { baseline and } 21 / 25 \text { at } \\
\text { follow-up ( } 100 \text { days after } \\
\text { SCT) }\end{array}$ & Positive psychosocial experience \\
\hline
\end{tabular}

\begin{tabular}{|c|c|c|}
\hline $\begin{array}{r}\text { Andersson } 2011 \\
\text { [24], Sweden }\end{array}$ & $\begin{array}{l}\text { Prospective } \\
\text { longitudinal, } \\
\text { comparative }\end{array}$ & $\begin{array}{l}\text { 202 SCT recipients: } \\
\text { - Autologous: } n=145(719 \\
\text { - MAC: } n=25(12 \%) \\
\text { - RIC: } n=32(15 \%)\end{array}$ \\
\hline $\begin{array}{l}\text { Bergkvist } 2016 \text { [25], } \\
\text { Sweden }\end{array}$ & $\begin{array}{l}\text { Qualitative } \\
\text { interviews }\end{array}$ & $\begin{array}{l}14 \text { family caregivers of } \\
\text { patients after allo-SCT }\end{array}$ \\
\hline
\end{tabular}

Sweden interviews
Symptoms and HRQL in the first year post-SCT Family members' life situation and
experiences of care $\begin{array}{lc}\text { Bergkvist } 2020 \text { [26], } & \text { Qualitative } \\ \text { Sweden } & \text { interviews }\end{array}$
14 family caregivers of patients 16 weeks after allo-SCT
Family caregivers' experiences of providing and receiving support during allo-HSCT
Bevans 2008 [27], Prospective USA

$$
\text { longitudinal }
$$

76 allo-SCT recipients $(54 \%$ RIC)
Symptoms in the first 100 days post-allo-SCT

\footnotetext{
Bevans 2014 [28], Prospective USA
}

171 allo-SCT survivors $\geq 3$ years
Family support and deliberate participation in pleasant and meaningful activities were the two primary sources of positive psychological experiences after allo-SCT. At baseline, participants consistently reported gratitude for their donors while follow-up was consistently characterized by hope for cure. Participants related bidirectional relationships between positive psychological well-being experiences and completion of health behaviors over time.

Overall: similar recovering in RIC and autologous groups; sign. worse scores in MAC group during the whole study period.

At 1 year: symptom and functioning scores back to BL or better in RIC and autologous group; worse in the MAC group in 10 of the 29 scales.

The findings show the family members' voice of the uncertainty in different ways, related with the unknown prognosis of the HSCT, presented as Being me being us in an uncertain time. Positive experiences such as freedom and security from home care were identified. Different strategies such as adjusting, having hope, and live in the present used to balance to live in an uncertain time.

Four prerequisites for family caregivers' ability to provide support: Individual characteristics influence the ability to be supportive, social context influences the ability to be supportive, medical information provides knowledge and a sense of participation and interaction with the healthcare organization provides a sense of participation.

Family caregivers' risk of experiencing a stronger sense of uncertainty and lack of participation is higher in the absence of the above-mentioned prerequisites.

Overall: multiple symptoms and high symptom distress at days 0 and 30 after transplant conditioning. By day 100: number of symptoms and total symptom distress comparable to BL.

Prevalent symptoms:

- BL: fatigue (68\%); worry (68\%)

- Day 0: appetite change (88\%); fatigue and insomnia (86\%); highest number of symptoms $(M d n=8(1-11)]$

- Day 30: fatigue (90\%)

- Day 100: fatigue (81\%)

Symptom distress: highest at day 0 , followed by day 30

Overall: mean scores for physical and mental health and HRQL preserved relative to population norms at 3 years or more.

Physical symptom distress: sign. predictor of worse physical and mental health status. Distress was significantly lower than healthy population values, and clinically meaningful: 73 (42.7\%) subjects reported high levels of symptoms distress $(>15)$, with a mean number of prevalent symptoms ranging 
Table 1 (continued)

$\begin{array}{llll}\begin{array}{l}\text { First author, year, } \\ \text { country }\end{array} & \text { Study design } & \text { Patient population } & \text { Main outcomes }\end{array}$

country

Busemann 2017

[29], Germany

Retrospective chart review

123 patients who died after allo-SCT

$\begin{array}{ccc}\text { Button 2014 [30], } & \begin{array}{c}\text { Retrospective } \\ \text { Australia } \\ \text { survey among } \\ \text { advanced } \\ \text { practice nurses }\end{array} & \begin{array}{c}40 \text { allo-SCT recipients who } \\ \text { relapsed and died }\end{array} \\ \text { Cappell 2018 [31], } & \begin{array}{c}\text { Retrospective } \\ \text { chart review }\end{array} & \begin{array}{c}422 \text { patients who died after } \\ \text { allo-SCT }\end{array}\end{array}$

Cohen 2012 [32], USA

Prospective longitudinal, comparative

164 SCT recipients:

- Autologous: $n=49$ (38\%)

- MAC: $n=49(30 \%)$

- RIC: $n=53(32 \%)$ $\begin{array}{cc}\text { Cusatis } 2020[33], & \begin{array}{c}\text { Prospective } \\ \text { longitudinal }\end{array}\end{array}$

Dunn 2016 [34], UK Qualitative interviews

184 allo-SCT recipients and survivors until 1-year post-allo-SCT

16 patients after allo-SCT
Somatic, psychic, and Spiritual needs

Patients characteristics, characteristics of
PC/end-of-life care

Documentation and timing of advance directive (AD); use of ICU and of mechanical ventilation after SCT; location of death

Symptoms and QoL, in the first 100 days post-SCT
Live experience after allo-SCT
Decisional regret about allo-SCT and association with QoL and clinical outcomes (relapse, GvHD), before allo-SCT, at day +100 , at month +6 and +12 post-allo-SCT across time from $12(\mathrm{SD} \pm 3)$ to $14(\mathrm{SD}$ \pm 4 ) symptoms (mean number of symptoms across the cohort: 8 to 10 )

- About $50 \%$ of patients did not live more than 5 months. Two-thirds died within 14 months after SCT.

- Major symptoms: weakness (48\% at last admission; $40 \% 7$ days before death), fatigue, and need for aid at daily activities. Severe pain, dyspnea, and obstipation were rare.

- Measures of intensive care and i.v.-drug administration were applied to a significant proportion of patients.

- Switch to a PC concept in 75/123 (61\%) cases; $35 \%$ of artificial ventilation in the final phase of life.

- $50 \%$ of patients seen by PC service

- Survey participants felt end-of-life discussions were left until the terminal phase. Participants believed early PC integration was beneficial for patients and their family.

- Prevalence: AD documentation prior to death: $44 \%$.

- Associations: patients with ADs less likely to use the ICU during the transplant course $(41 \%$ for patients with Ads versus $52 \%$ of patients without Ads; $p=.03$ ); less likely to receive mechanical ventilation at any point after SCT $(21 \%$ versus $37 \%, p<.001)$; decreased ICU use at the end-of-life; more likely to die at home or in hospital as opposed to in the ICU (odds ratio, .44; 95\% CI .27/.72)

Overall: MAC group showed more severe sleep disturbance and poorer QOL than autologous group. Patients with acute GvHD had sign. more severe symptoms.

At day +100 post-allo-SCT:

- RIC group: higher score for the "worst five symptoms" (fatigue, sleep disturbance, physically weak, drowsiness, and lack of appetite) and for physical weakness than autologous group

- MAC group: higher scores for the "worst five symptoms," for fatigue, and for physical weakness than autologous group

Decisional regret: $6 \%$ to $8 \%$ of patients expressed regret at day +100 , month +6 and +12 post-allo-SCT; a total of $15 \%$ expressed regret at any time point.

Associations: Regret was associated with:

- Lower QoL scores at 6 months and 12 months $(p<.001)$

- Lower baseline QoL and social well-being

- Disease recurrence: $17.5 \%$ (95\% CI, $5.5-29.7 \%)$ greater risk

The Immediacy of Illness and Existential Crisis developed from participants' experiences of critical events accompanied by enduring uncertainty continuing into the recovery period. Participants suffer major disruption to their lives physically, psychosocially, and emotionally, including facing their own mortality, without a sense of when 
Table 1 (continued)

First author, year, $\quad$ Study design $\quad$ Patient population $\quad$ Main outcomes $\quad$ Main results on allo-SCT

country

El-Jawahri 2015 [35, Prospective 36], USA longitudinal
90 SCT recipients and their family caregivers (FC):

- Autologous: $n=30$

- MAC: $n=30$

- RIC: $n=30$

they may resume the normality of their former lives.

QoL and mood of patients and FC during QoL: sign. decline of patients' and FC QoL hospitalization for SCT (from day-6 Mood: sign. increase of patients' and FC pre-SCT to day+8 post-SCT) [36]; depression; anxiety in patients and FC

Prognostic understanding and its stable. association with QoL and mood [35] Prognostic understanding:

- $88.9 \%$ of patients and $87.1 \%$ of FC reported it is "extremely" or "very" important to know about prognosis.

- Prognostic understanding: more optimistic than the oncologist's in $77.6 \%$ of patients and $71.7 \%$ of FC $(p<$ $0.0001)$

- Association with QoL/mood: patients with a concordant prognostic understanding with their oncologists had worse QoL $(\beta=-9.4, p=0.01)$ and greater depression at $\mathrm{BL}(\beta=1.7, p=$ $0.02)$ and over time $(\beta=1.2, p<$ $0.0001)$

El-Jahwari 2016 [20] / 2017 [21], USA
Randomized controlled trial, - Intervention: inpatient PC non-blinded $=80$

- Control: standard SCT care: $n$ $=80$

stratified by transplant type: autologous 50\%, MAC $19 \%$, RIC $31 \%$
Esser 2017 [37-39]/ Prospective Kuba 2017 [40, longitudinal, 41] / Sarkar 2014 comparative [42], Germany
Allo-SCT recipients/ survivors:

- T0 (pre-condition-ing) : $n=$ 239

- T1 (day 100 post-SCT): $n=$ 150

- T2 (1 year): $n=102$

- T3 (5 years): $n=45$

Control group (general population) drawn from large representative samples in Germany, age- and gender-matched
Symptoms (fatigue [37], anxiety and depression [40], others [38]), PTSD [39], cancer-and-treatment-specific distress [41], and fear of recurrence [42]
Symptoms (fatigue, anxiety, depression), PC (intervention) group: symptom burden and QoL, at 2 weeks post-hospitalization [20], and 6 months [21] post-SCT
- Sign. improvement in QOL (Functional Assessment of Cancer Therapy - Bone Marrow Transplantation, FACT-BMT: mean difference between groups -6.82 (95\% CI: -13.48 to $0.16 ; p=0.045$ ), symptom burden, depression and anxiety symptoms at 2 weeks post-SCT

- Sign. improvement in depression symptoms and post-traumatic stress symptoms at 6 months after SCT

- Caregivers: improvement in depression symptoms at 2 weeks

The effect of the intervention did not differ by transplant type.

Global fatigue:

- T0 to T1: sign. increase $(t=3.85, p<$ $0.001)$

- T1 to T2: sign. decrease $(t=-2.92, p=$ $0.004)$, then stable

- T0 to T3: non-sign. difference $(t=0.68, p$ $=0.497$ ).

- Allo-SCT vs. general population: higher global fatigue at T0 $(t=-6.02, p<$ $0.001)$ and T3 $(t=-2.50, p=0.014)$; meaningful effect sizes $(d \geq 0.5)$.

- Predictors of fatigue: acute and chronic GvHD at $\mathrm{T} 1$ and $\mathrm{T} 2$, respectively

Depression:

- T2 to T3: sign. increase of prevalence rates from 12 to $30 \%$

- Allo-SCT vs. general population: sign. lower RR at T0 $(\mathrm{RR}=0.56 ; 95 \% \mathrm{CI}$ $0.4 / 0.8)$ and $\mathrm{T} 2(\mathrm{RR}=0.47 ; 95 \% \mathrm{CI}$ $0.3 / 0.8)$; at T1 and T3: non-sign.

Anxiety:

- T0 to T1: sign. decrease of prevalence rates of anxiety from 29 to $19 \%$

- T1 to T2/T3: stable

- Allo-SCT vs. general population: sign. increased at T0 $(\mathrm{RR}=1.31 ; 95 \% \mathrm{CI}$ 1.02/1.68); from $\mathrm{T} 1$ on: non-sign.

Symptom clusters (SC): 3 stable SC (present at 3 consecutive time points): rest-tired-weak-dyspnea-loss of appetite, tense-worried-irritable-depressed, and nausea-vomiting

PTSD symptomatology:

- $15 \%$ met the criteria for PTSD at least once during the course of assessment. 
Table 1 (continued)

First author, year, $\quad$ Study design $\quad$ Patient population $\quad$ Main outcomes $\quad$ Main results on allo-SCT
country

$\begin{array}{ccc}\begin{array}{c}\text { Grulke 2010 [43], } \\ \text { Germany }\end{array} & \begin{array}{c}\text { Prospective } \\ \text { longitudinal; } \\ \text { survey among } \\ \text { physicians }\end{array} & \begin{array}{c}136 \text { allo-SCT recipients (72 } \\ \text { died during the 2-years } \\ \text { follow-up) }\end{array} \\ \text { Han 2019 [44], USA } & \begin{array}{c}\text { Retrospective } \\ \text { chart review }\end{array} & \begin{array}{c}21458 \text { hospitalized SCT } \\ \text { recipients (40\% allo-SCT) }\end{array}\end{array}$

Hefner 2014 [45], Cross-sectional Germany

Heinonen 2005 [46], Survey Finland
Comparison of physician prognostic estimates and patient survival

General prevalence, temporal trends, and predictors of PC use from 2008 to 2014

Distress (anxiety, fear of progression, depression, PTSD) /survivors (mean time after transplantation: 614 days (25 to 2070 days))

109 allo-SCT recipients

Identification of stressors

- $52 \%$ showed diagnostic relevant levels of intrusion, $30 \%$ of avoidance, and $33 \%$ of arousal at least once.

- Sign. predictors at all time points: being impaired by pain $(\gamma=2.89, p<0.01)$, pain level $(\gamma=0.63, p=0.02)$, and being female $(\gamma=3.81, p<0.01)$

- Sign. predictors at T2: acute and chronic GvHD, longer hospital stay

Cancer-and-treatment-specific distress (CTXD): sum score of CTXD was highest at $\mathrm{T} 0$, then decreased by $\mathrm{T} 1(\gamma=$ $-.18,95 \% \mathrm{CI}-.26 /-.09)$, and by T2 $(\gamma$ $=-.10,95 \% \mathrm{CI}-.20 /-.00)$. Subscales: uncertainty, family strain, and health burden were rated most distressing during SCT.

Fear of recurrence:

- Prevalence of high fear of recurrence: T0: 36\%; T1: $24 \%$ of patients; T2: $23 \%$

- Predictors: T0: being married $(b=2.76, p$ $=0.026)$, female gender $(b=4.45, p<$ $0.001)$, and depression $(b=4.44, p<$ $0.001)$ were significantly associated with FCR at baseline. T1: depression ( $b$ $=6.46, p<0.001)$. T2: female gender $(b$ $=6.61, p=0.008)$, higher depression $(b$ $=4.88, p=0.004$ )

- Associations: fear of recurrence and lower physical functioning ( $p=0.019)$, role functioning $(p=0.003)$, emotional functioning $(p=0.001)$, cognitive functioning ( $p=0.003)$, social functioning $(p=0.001)$, and global QoL $(p<0.001)$.

Physicians' estimates associated with overall survival (univariate Cox regression: hazard ratio $=1.51,95 \% \mathrm{CI}$ $=1.24-1.82$ )

Rate of PC use:

- Among SCT: $1.30 \%$ (278/21 458)

- Among allo-SCT: $1.95 \%$

Rate of PC use from 2008 to 2014:

- Among SCT: sign. increase (annual percentage change: $12.96 \%$ )

- Among allo-SCT: sign. increase (annual percentage change: $16.45 \%$ )

Predictors of higher PC use in allo-SCT: higher comorbidities $(\mathrm{OR}=3.19 ; 95 \%$ CI 1.77/5.77; $p=.0001)$ and GvHD $(\mathrm{OR}=2.04 ; 95 \%$ CI 1.36/3.06; $p=$ .0006)

Prevalence rates: symptoms of distress in total: $n=18$ (44\%), of which: symptoms of anxiety: $n=11(27 \%)$; fear of progression: $n=12(29 \%)$; symptoms of depression: $n=11(27 \%)$; symptoms of PTSD: $n=6(15 \%)$

Associations: age $<55$ years significantly associated with fear of progression ( $p=$ 0.004). No association between distress and acute or chronic GvHD or time after allo-SCT

Identification of 8 stress clusters (from the most severe to the least severe): change of life and impact of long-lasting treatment; side effects; distress related to treatment outcome and physiological status; family-related stress; fear of death and depressive thoughts; other concerns; negative social support; and 
Table 1 (continued)

First author, year, $\quad$ Study design $\quad$ Patient population $\quad$ Main outcomes $\quad$ Main results on allo-SCT

country

Loggers $2016[47]$,
USA $\begin{gathered}\text { Prospective } \\ \text { longitudinal }\end{gathered} 2$ allo-SCT recipients

Scherwath 2013

[48], Germany

Prospective

longitudinal

102 allo-SCT recipients

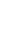

\section{Schulz-Kindermann 2007 [49], \\ Germany \\ Prospective \\ longitudinal}

39 allo-SCT recipients

Valkova 2016 [50], Retrospective

Czech Republic chart review

590 allo-SCT recipients $(64 \%$ MAC, 36\% RIC)

602 SCT recipients (39\% allo-SCT) stress related to lack of information and the medical staff.

Feasibility and acceptability of pre-SCT - Comfort with early PC: high (82\% very early PC comfortable)

- Mood, sense of hope: stable or improved subjective mood and sense of hope

- Follow-up surveys (60 day 60 and 90): 4 (20\%) admitted to the ICU before day 100 and $3(15 \%)$ received life-support measures. $5(25 \%)$ died with median follow-up of 14 months.

Cognitive function (attention, memory, executive function, fine motor function), at T0, T1 (100 days), and T2 (1 year)

Comparison with test norms: below test norms in up to $50 \%$ of the test scores. Patients were mostly impaired on word fluency $(24 \%$, T0), fine motor function, and verbal delayed recall (19\% each, $\mathrm{T} 2$ ).

Over time: partial improvement in performance (i.e., visual span forward, verbal learning, and word fluency). However, from T0 to T2, $16 \%$ of the patients showed reliable decline on $\geq 3 / 14$ test scores.

Associations: no associations with conditioning intensity, total body irradiation, GvHD, cyclosporine treatment, and length of hospital stay for most of neuropsychological subtests

Cognitive function (attention, memory, executive function), at T0 and T1 (100 days)

Comparison with test norms: mostly no sign. differences at $\mathrm{T} 0$ or $\mathrm{T} 1$, except verbal long-term memory ( $\mathrm{T} 0$ and $\mathrm{T} 1$ ) and visual working memory (T1) below norm.

Over time: sign. prolonged simple reaction time

Associations: no association with extent of pretreatment, GvHD, or conditioning protocol

Overall QoL: lowest score immediately after allo-SCT, with subsequent higher score after 100 days, followed by lower score in the period between 1 and 2 years, and then a sustained increase. Scores: $73 \%$ of the maximum values at 1 year, $80 \%$ at 3 years, and $82 \%$ at 5 years.

Predictors of worse QoL: acute and chronic GVHD in the last 6 months (regardless of the extent); increasing age

Prevalence of PC consultation: $19 \%(n=$ 114) of SCT patients, with $83 \%(n=95)$ occurring in the hospital. Sign. difference between transplant types with $11 \%$ of allo-SCT $(n=68)$ and $8 \%$ of autologous SCT $(n=46)$ receiving PC

$\mathrm{AD} / \mathrm{POLST}$ completion rate:

- $44 \%$ of SCT patients $(n=267)$

- Allo-SCT: sign. greater rate than autologous SCT (OR, 1.56; 95\% CI, 1.12 to $2.17 ; p=.008$ )

Hospice enrollment rate: $15 \%(n=17)$

Abbreviations: allo-SCT, allogeneic stem cell transplantation; $B L$, baseline; $C I$, confidence interval; $F C$, family caregivers; $G v H D$, graft-versus-host disease; $H R Q L$, health-related quality of life; $I C U$, intensive care unit; $M A C$, myeloablative conditioning; $O R$, odd ratio; $P C$, palliative care; $P T S D$, posttraumatic stress disorder; $Q o L$, quality of life; $R I C$, reduced-intensity conditioning; $R R$, relative risk; $S D S$, symptom distress score; sign., significant

received a consultation by a palliative care consultant at least twice a week during the time of hospitalization and the control group received standard transplant care. Randomization was stratified by transplant type (autologous, myeloablative 
allogeneic, or RIC allogeneic) with half of the patients receiving an allo-SCT. Transplant type was not found to be a mediator of the effect of the intervention. In the interventional arm, patients showed less reduction in quality of life at 2 weeks after admission, which was significant and clinically relevant (Functional Assessment of Cancer Therapy - Bone Marrow Transplantation [FACT-BMT]: mean difference between the groups -6.82 [95\% CI: -13.48 to $0.16 ; p=0.045]$ ). Among secondary endpoints, at 2 weeks post-SCT, anxiety was significantly lower in the interventional group, while depression and symptom burden increased significantly less, and levels of fatigue did not differ. At 3 months post-SCT, quality of life was higher and symptoms of depression were lower in the interventional group [20]. At 6 months, the significant differences for the parameter of depression persisted and symptoms of a post-traumatic stress disorder were lower in the interventional arm [21].

\section{Family caregivers}

The impact of allo-SCT also extends to the family caregivers, who play a key role in caring for patients after discharge from the hospital $[52,64]$. Most of them are spouses. They experience an increased level of anxiety and symptoms of depression as well as physical symptoms like fatigue, sleep disturbances, weight loss, and changes in marital and social life [64]. Their own burden might also have an impact on patients' outcomes, like mental health or number of hospitalizations [64]. More research is needed to better understand the interrelation between the needs of patients and their caregivers, and to develop targeted interventions. First results of psychological interventions are promising $[66,67]$. The early integration of specialized palliative care in standard allo-SCT procedures might also positively affect caregivers' outcomes, as shown in the mentioned RCT [20]: caregivers of patients in the intervention group had a significantly smaller increase in depression at 2 weeks as compared to caregivers of patients in the standard care arm; however, no significant differences in quality of life or anxiety were found at that time point.

\section{Unpredictable illness trajectory and prognosis: uncertainty, fear of recurrence, and death anxiety}

Allo-SCT has a high potential to provide long-term remissions of the underlying hematologic disease, but it is also associated with a high mortality $[1,2,4]$. In this context, uncertainty, death anxiety, and fear of recurrence are further sources of distress that patients experience in the context of an alloSCT $[41,42,46]$.
In allo-SCT recipients, uncertainty emerges as a main cause of burden and suffering [25, 26, 34-36, 43]. In a prospective cohort of 239 patients undergoing allo-SCT, uncertainty was found to be one of the predictive factors for symptoms of post-traumatic stress disorder before, 3, and 12 months after transplantation [41]. The authors hypothesized that the high uncertainty level may be due to the complex and unpredictable nature of allo-SCT, which is in line with findings on the first descriptions of patient's uncertainty in unspecific illness situations [68-70]. Mishel, for instance, delineated four forms of uncertainty in a general context of illness: ambiguity regarding the state of the illness, complexity of treatment, lack of information, and unpredictability of prognosis [70]. Uncertainty in advanced illnesses like metastatic cancers has been addressed by various authors [68, 71, 72]. They confirm Mishel's four forms of uncertainty, with complexity and unpredictability of illness being the most relevant factors at the end of life [68]. However, the exact components of uncertainty in the allo-SCT population and the ways to communicate and to manage still need to be explored [69, 73].

Fear of recurrence has been defined as the "fear, worry or concern relating to the possibility that cancer will come back or progress" [74]. Although it can be considered so far as a normal response to a cancer diagnosis, it may lead in some cases to dysfunctions like difficulties in sleeping and anxiety as well as to a decreased quality of life [75]. It therefore requires special consideration in clinical practice. The few research findings available for patients after allo-SCT indicate that about a third of them suffer from fear of recurrence [42, 45].

Fear of death is another important stress factor in allo-SCT [46]. However, it has hardly been explored to date and data from patients undergoing SCT are missing so far. A survey with 109 patients highlights fear of death as one of the main components of stress in allo-SCT, among other factors like change of life, side effects, or family concerns [46]. Prevalence rates for fear of death in patients with advanced cancer range from 30 to $80 \%$ [76, 77]. In patients treated for hematologic disease with a curative intent, preoccupation with death was found to be associated with higher anxiety and depression rates as well as with reduced coping [78]. Recently, interventions addressing death anxiety were developed (overview in [79]), but do not address allo-SCT recipients specifically.

To what extent fear of recurrence, death anxiety, and uncertainty are interrelated has been addressed rather rudimentarily [80-82]. Raising this issue could help to better understand distress in allo-SCT recipients and to optimize current management strategies.

\section{End-of-life care in patients with allo-SCT}

When the underlying disease fails to respond to the allo-SCT modality or side effects such as infectious complications or 
refractory GvHD become incurable, the patient's condition often deteriorates quickly. The goal of care then needs to be adapted to focus on an effective symptom control and to improve the quality of life. Life-prolonging treatments (including blood transfusion) are often stopped at this point. After this change of goals of care from life-prolonging to end-of-life care, the time until death is often short [29-31].

The last phase of life, including the dying phase, has been investigated in some studies on patients with hematologic cancers $[16,51,83-86]$. Their findings suggest a similar symptom burden and decline in the last 3 months of life as compared to patients with solid tumors $[83,85]$. For end-oflife care in patients with allo-SCT, studies are missing so far, besides two retrospective chart reviews with participants who died after allo-SCT; the patients had an elevated burden of symptoms $[29,30]$. Further research is necessary to explore distress and needs of patients with allo-SCT and their informal caregivers and to describe the illness trajectory in the last phase of life.

\section{Early integration of palliative care in the standard care of patients with allo-SCT}

The early integration of specialist palliative care expertise in the transplant procedure aims at improving the experience of patients and caregivers throughout the individual trajectory, irrespective of whether that involves cure, chronic comorbidity, or death. This is achieved by improving symptom control, preventing and palliating psychosocial distress, enhancing patients' and caregivers' coping, and - if death nears - by caring through the last phase of life and by supporting caregivers' bereavement [19-21, 87, 88]. This has been an emerging issue over the last years.

In general, the use of specialist palliative care services for patients with allo-SCT is rather infrequent, although it appears to have increased in recent years. A large retrospective USAmerican chart review of 21,458 patients hospitalized for SCT (40\% with an allo-SCT) describes that $1.95 \%$ of alloSCT recipients received specialized palliative care [44]. There was a significant increase in its use from 2008 to 2014 (annual percentage change 16.45\%). Among the patients who died during hospitalization, the rate of involved palliative care services was only $33.40 \%$ [44].

Barriers resulting in the late and low rate of integration of specialist palliative care into the therapeutic algorithms in hematology have been described in general reviews on hematologic malignancies [14, 55, 89-91]. Their results are also applicable to the specific context of allo-SCT. They describe disease-related barriers like the unpredictable course of hematologic diseases or the unclear interface between a curative and palliative stage. Subjective factors play an important role as well, e.g., the perception that palliative care refers exclusively to the last phase of life, the fear to reduce patients' hope, unrealistic expectations of patients, family members, and clinicians, or suboptimal collaborations between the disciplines of hematologists and palliative care experts [14, 55, 89-91].

Several models of integration of specialist palliative care in (allo)-SCT have been proposed, ranging from a selective palliative care consult ordered by the transplant team to the upfront integration of palliative care specialists in routine transplant care [19, 87]. However, such models of integration are implemented only in few institutions worldwide and thorough analyses of real-world clinical experiences are missing so far $[19,87]$. Research on the efficacy of these models is also scarce. The RCT of El-Jawahri et al. mentioned previously confirmed the effectiveness of a consultative model on improving symptoms and quality of life [20,21]. Further studies with a non-controlled prospective design supported the effectivity of other consultative models on palliative outcomes such as goals-of-care discussions, hospice referral, and keeping up hopes after talking to palliative care professionals [47, 92]. There is a need for research also on other models of integration such as co-rounding, embedded models with routine inclusion of palliative care, or models for allo-SCT survivors [19].

\section{Discussion}

\section{Impact for clinical care}

Integrating specialist palliative care early in the course of the allo-SCT procedure likely contributes to achieve the best possible symptom control, to help patients and caregivers to better cope with the illness and its prognosis (including distress by uncertainty, fear of recurrence, and death anxiety), and to optimize quality of life $[17,19,47,55,87,88]$. Strategies for an early integration should be adapted to the specific issues of transplantation, as already implemented in some few projects $[20,21]$. Structured interventional strategies (programs) along the whole transplant trajectory are likely to be more effective then sporadic on-demand involvements. A main issue around integrating palliative care in clinical SCT practice remains a regular contact and communication between transplant physicians and palliative care specialists in order to ensure a best possible collaboration between both disciplines. A further issue is the adequate information of patients about the advantage of integrating palliative care, even before transplantation.

\section{Impact for research}

Overall, there is a high need for further research on burden, needs, and coping of allo-SCT patients and their caregivers, regarding physical symptoms as well as psychosocial distress when facing an uncertain prognosis and death. There is also an urgent need for interventional studies evaluating the most effective strategies to integrate specialist palliative care into the allo- 
SCT setting. It is furthermore highly warranted to systematically assess the effect of integration of psycho-oncology, psychosocial, and supportive care services in transplant procedures on outcome parameters such as quality of life in comparison to the impact of integration of specialized palliative care.

\section{Conclusion}

During the past decades, survival of patients after allo-SCT has continually improved. Despite such better prognoses and the reduction of treatment complications, morbidity and mortality remain relatively high in this patient population. We need to better integrate palliative care into the standard care of patients with allo-SCT in order to improve symptom control, to enhance the prevention and support of psychosocial distress, and to provide best care at the end of life. Wellconducted studies around these topics are still scarce, although becoming more frequent, as far as we can judge from the results of this non-systematic review. They are urgently needed to provide best possible care and quality of life for patients undergoing an allo-SCT.

Code availability Not applicable.

Funding Open Access funding enabled and organized by Projekt DEAL.

\section{Declaration}

Ethics approval Not applicable.

Consent to participate Not applicable.

Consent for publication Not applicable.

Conflict of interest The authors declare no competing interests.

Open Access This article is licensed under a Creative Commons Attribution 4.0 International License, which permits use, sharing, adaptation, distribution and reproduction in any medium or format, as long as you give appropriate credit to the original author(s) and the source, provide a link to the Creative Commons licence, and indicate if changes were made. The images or other third party material in this article are included in the article's Creative Commons licence, unless indicated otherwise in a credit line to the material. If material is not included in the article's Creative Commons licence and your intended use is not permitted by statutory regulation or exceeds the permitted use, you will need to obtain permission directly from the copyright holder. To view a copy of this licence, visit http://creativecommons.org/licenses/by/4.0/.

\section{References}

1. Gooley TA, Chien JW, Pergam SA, Hingorani S, Sorror ML, Boeckh M, Martin PJ, Sandmaier BM, Marr KA, Appelbaum FR,
Storb R, McDonald GB (2010) Reduced mortality after allogeneic hematopoietic-cell transplantation. N Engl J Med 363(22):20912101. https://doi.org/10.1056/NEJMoa1004383

2. Majhail NS (2017) Long-term complications after hematopoietic cell transplantation. Hematol Oncol Stem Cell Ther 10(4):220 227. https://doi.org/10.1016/j.hemonc.2017.05.009

3. Majhail NS, Rizzo JD (2013) Surviving the cure: long term followup of hematopoietic cell transplant recipients. Bone Marrow Transplant 48(9):1145-1151. https://doi.org/10.1038/ bmt.2012.258

4. Friedrichs B, Tichelli A, Bacigalupo A, Russell NH, Ruutu T, Shapira MY, Beksac M, Hasenclever D, Socie G, Schmitz N (2010) Long-term outcome and late effects in patients transplanted with mobilised blood or bone marrow: a randomised trial. Lancet Oncol 11(4):331-338. https://doi.org/10.1016/S1470-2045(09) 70352-3

5. Worldwide Palliative Care Alliance/World Health Organization (2014) Global atlas of palliative care at the end of life. https:// www.who.int/nmh/Global_Atlas_of_Palliative_Care.pdf. Accessed August 2020

6. Bausewein C, Simon ST, Pralong A, Radbruch L, Nauck F, Voltz R (2015) Palliative care of adult patients with cancer. Dtsch Arztebl Int 112(50):863-870. https://doi.org/10.3238/arztebl.2015.0863

7. Radbruch L, Payne S (2009) White Paper on standards and norms for hospice and palliative care in Europe: part 1. Eur J Palliat Care 16(6):278-289

8. Simon ST, Pralong A, Radbruch L, Bausewein C, Voltz R (2020) The palliative care of patients with incurable cancer. Dtsch Arztebl Int 116(7):108-115. https://doi.org/10.3238/arztebl.2020.0108

9. Ferrell BR, Temel JS, Temin S, Alesi ER, Balboni TA, Basch EM, Firn JI, Paice JA, Peppercorn JM, Phillips T, Stovall EL, Zimmermann C, Smith TJ (2017) Integration of palliative care into standard oncology care: American Society of Clinical Oncology Clinical Practice Guideline Update. J Clin Oncol 35(1):96-112

10. National Coalition for Hospice and Palliative Care (2018) Clinical practice guidelines for quality palliative care, 4th edition. https:// www.nationalcoalitionhpc.org/wp-content/uploads/2018/10/ NCHPC-NCPGuidelines_4thED_web_FINAL.pdf. Accessed September 2020

11. National Comprehensive Cancer Network (NCCN) (2020) Palliative care, Version 1.2020. https://www.nccn.org/guidelines/ guidelines-detail?category $=3 \& i d=1454$. Accessed August 2020

12. Gaertner J, Siemens W, Meerpohl JJ, Antes G, Meffert C, Xander C, Stock S, Mueller D, Schwarzer G, Becker G (2017) Effect of specialist palliative care services on quality of life in adults with advanced incurable illness in hospital, hospice, or community settings: systematic review and meta-analysis. BMJ 357:j2925. https:// doi.org/10.1136/bmj.j2925

13. Haun MW, Estel S, Rucker G, Friederich HC, Villalobos M, Thomas M, Hartmann M (2017) Early palliative care for adults with advanced cancer. Cochrane Database Syst Rev 6:CD011129. https://doi.org/10.1002/14651858.CD011129.pub2

14. Howell DA, Shellens R, Roman E, Garry AC, Patmore R, Howard MR (2011) Haematological malignancy: are patients appropriately referred for specialist palliative and hospice care? A systematic review and meta-analysis of published data. Palliat Med 25(6): 630-641. https://doi.org/10.1177/0269216310391692

15. Beaussant Y, Daguindau E, Chauchet A, Rochigneux P, Tournigand C, Aubry R, Morin L (2018) Hospital end-of-life care in haematological malignancies. BMJ Support Palliat Care 8(3): 314-324. https://doi.org/10.1136/bmjspcare-2017-001446

16. Eichenauer DA, Golla H, Thielen I, Hallek M, Voltz R, Perrar KM (2019) Characteristics and course of patients with advanced hematologic malignancies receiving specialized inpatient palliative care at a German university hospital. Ann Hematol 98:2605-2607. https://doi.org/10.1007/s00277-019-03748-1 
17. LeBlanc TW, El-Jawahri A (2018) Hemato-oncology and palliative care teams: is it time for an integrated approach to patient care? Curr Opin Support Palliat Care 12(4):530-537. https://doi.org/10.1097/ SPC.0000000000000385

18. Oechsle K (2019) Palliative care in patients with hematological malignancies. Oncol Res Treat 42(1-2):25-30. https://doi.org/10. $1159 / 000495424$

19. Mitchell SA (2018) Palliative care during and following allogeneic hematopoietic stem cell transplantation. Curr Opin Support Palliat Care 12(1):58-64. https://doi.org/10.1097/SPC. 0000000000000327

20. El-Jawahri A, LeBlanc T, VanDusen H, Traeger L, Greer JA, Pirl WF, Jackson VA, Telles J, Rhodes A, Spitzer TR, McAfee S, Chen YA, Lee SS, Temel JS (2016) Effect of inpatient palliative care on quality of life 2 weeks after hematopoietic stem cell transplantation: a randomized clinical trial. JAMA 316(20):2094-2103. https://doi. org/10.1001/jama.2016.16786

21. El-Jawahri A, Traeger L, Greer JA, VanDusen H, Fishman SR, LeBlanc TW, Pirl WF, Jackson VA, Telles J, Rhodes A, Li Z, Spitzer TR, McAfee S, Chen YA, Temel JS (2017) Effect of inpatient palliative care during hematopoietic stem-cell transplant on psychological distress 6 months after transplant: results of a randomized clinical trial. J Clin Oncol 35(32):3714-3721. https://doi. org/10.1200/JCO.2017.73.2800

22. El-Jawahri A, LeBlanc TW, Kavanaugh A, Webb J, Jackson VA, Campbell TC, O'Connor N, Luger SM, Gafford E, Gustin J, Bhatnagar B, Fathi AT, Hobbs G, Foster J, Nicholson S, Davis DM, Addis H, Vaughn D, Horick NK, Temel JS (2020) Multisite randomized trial of integrated palliative and oncology care for patients with acute myeloid leukemia (AML). J Clin Oncol 38 (15 suppl):12000. https://doi.org/10.1200/JCO.2020.38.15 suppl. 12000

23. Amonoo HL, Brown LA, Scheu CF, Millstein RA, Pirl WF, Vitagliano HL, Antin JH, Huffman JC (2019) Positive psychological experiences in allogeneic hematopoietic stem cell transplantation. Psychooncology 28(8):1633-1639. https://doi.org/10.1002/ pon. 5128

24. Andersson I, Ahlberg K, Stockelberg D, Persson LO (2011) Patients' perception of health-related quality of life during the first year after autologous and allogeneic stem cell transplantation. Eur J Cancer Care (Engl) 20(3):368-379. https://doi.org/10.1111/j.13652354.2009.01174.x

25. Bergkvist K, Larsen J, Johansson UB, Mattsson J, Fossum B (2018) Family members' life situation and experiences of different caring organisations during allogeneic haematopoietic stem cells transplantation-a qualitative study. Eur J Cancer Care (Engl) 27(1). https://doi.org/10.1111/ecc. 12610

26. Bergkvist K, Winterling J, Kisch AM (2020) Support in the context of allogeneic hematopoietic stem cell transplantation - the perspectives of family caregivers. Eur J Oncol Nurs 46:101740. https://doi. org/10.1016/j.ejon.2020.101740

27. Bevans MF, Mitchell SA, Marden S (2008) The symptom experience in the first 100 days following allogeneic hematopoietic stem cell transplantation (HSCT). Support Care Cancer 16(11):12431254. https://doi.org/10.1007/s00520-008-0420-6

28. Bevans MF, Mitchell SA, Barrett JA, Bishop MR, Childs R, Fowler D, Krumlauf M, Prince P, Shelburne N, Wehrlen L, Yang L (2014) Symptom distress predicts long-term health and well-being in allogeneic stem cell transplantation survivors. Biol Blood Marrow Transplant 20(3):387-395. https://doi.org/10.1016/j.bbmt.2013. 12.001

29. Busemann C, Julich A, Buchhold B, Schmidt V, Schneidewind L, Pink D, Schmidt CA, Neumann T, Kruger WH (2017) Clinical course and end-of-life care in patients who have died after allogeneic stem cell transplantation. J Cancer Res Clin Oncol 143(10): 2067-2076. https://doi.org/10.1007/s00432-017-2446-y
30. Button EB, Gavin NC, Keogh SJ (2014) Exploring palliative care provision for recipients of allogeneic hematopoietic stem cell transplantation who relapsed. Oncol Nurs Forum 41(4):370-381. https:// doi.org/10.1188/14.ONF.370-381

31. Cappell K, Sundaram V, Park A, Shiraz P, Gupta R, Jenkins P, Periyakoil VSJ, Muffly L (2018) Advance directive utilization is associated with less aggressive e-of-life care in patients undergoing allogeneic hematopoietic cell transplantation. Biol Blood Marrow Transplant 24(5):1035-1040. https://doi.org/10.1016/j.bbmt.2018. 01.014

32. Cohen MZ, Rozmus CL, Mendoza TR, Padhye NS, Neumann J, Gning I, Aleman A, Giralt S, Cleeland CS (2012) Symptoms and quality of life in diverse patients undergoing hematopoietic stem cell transplantation. J Pain Symptom Manag 44(2):168-180. https://doi.org/10.1016/j.jpainsymman.2011.08.011

33. Cusatis RN, Tecca HR, D'Souza A, Shaw BE, Flynn KE (2020) Prevalence of decisional regret among patients who underwent allogeneic hematopoietic stem cell transplantation and associations with quality of life and clinical outcomes. Cancer 126(11):2679 2686. https://doi.org/10.1002/cncr.32808

34. Dunn E, Arber A, Gallagher A (2016) The immediacy of illness and existential crisis: patients' lived experience of under-going allogeneic stem cell transplantation for haematological malignancy. A phenomenological study. Eur J Oncol Nurs 21:90-96. https://doi. org/10.1016/j.ejon.2016.01.001

35. El-Jawahri A, Traeger L, Kuzmuk K, Eusebio J, Vandusen H, Keenan T, Shin J, Gallagher ER, Greer JA, Pirl WF, Jackson VA, Ballen KK, Spitzer TR, Graubert TA, McAfee S, Dey B, Chen YB, Temel JS (2015) Prognostic understanding, quality of life and mood in patients undergoing hematopoietic stem cell transplantation. Bone Marrow Transplant 50(8):1119-1124. https://doi.org/ 10.1038/bmt.2015.113

36. El-Jawahri AR, Traeger LN, Kuzmuk K, Eusebio JR, Vandusen HB, Shin JA, Keenan T, Gallagher ER, Greer JA, Pirl WF, Jackson VA, Ballen KK, Spitzer TR, Graubert TA, McAfee SL, Dey BR, Chen YB, Temel JS (2015) Quality of life and mood of patients and family caregivers during hospitalization for hematopoietic stem cell transplantation. Cancer 121(6):951-959. https://doi. org/10.1002/cncr.29149

37. Esser P, Kuba K, Mehnert A, Schwinn A, Schirmer L, SchulzKindermann F, Kruse M, Koch U, Zander AR, Kroger N, Schilling G, Gotze H, Scherwath A (2017) Investigating the temporal course, relevance and risk factors of fatigue over 5 years: a prospective study among patients receiving allogeneic HSCT. Bone Marrow Transplant 52(5):753-758. https://doi.org/10.1038/bmt. 2016.344

38. Esser P, Kuba K, Scherwath A, Johansen C, Schwinn A, Schirmer L, Schulz-Kindermann F, Kruse M, Koch U, Zander AR, Kroger N, Gotze H, Mehnert A (2017) Stability and priority of symptoms and symptom clusters among allogeneic HSCT patients within a 5-year longitudinal study. J Pain Symptom Manag 54(4):493-500. https:// doi.org/10.1016/j.jpainsymman.2017.07.012

39. Esser P, Kuba K, Scherwath A, Schirmer L, Schulz-Kindermann F, Dinkel A, Balck F, Koch U, Kroger N, Gotze H, Mehnert A (2017) Posttraumatic stress disorder symptomatology in the course of allogeneic HSCT: a prospective study. J Cancer Surviv 11(2):203210. https://doi.org/10.1007/s11764-016-0579-7

40. Kuba K, Esser P, Mehnert A, Johansen C, Schwinn A, Schirmer L, Schulz-Kindermann F, Kruse M, Koch U, Zander A, Kroger N, Gotze H, Scherwath A (2017) Depression and anxiety following hematopoietic stem cell transplantation: a prospective populationbased study in Germany. Bone Marrow Transplant 52(12):16511657. https://doi.org/10.1038/bmt.2017.190

41. Kuba K, Esser P, Scherwath A, Schirmer L, Schulz-Kindermann F, Dinkel A, Balck F, Koch U, Kroger N, Gotze H, Mehnert A (2017) Cancer-and-treatment-specific distress and its impact on 
posttraumatic stress in patients undergoing allogeneic hematopoietic stem cell transplantation (HSCT). Psychooncology 26(8):1164 1171. https://doi.org/10.1002/pon.4295

42. Sarkar S, Scherwath A, Schirmer L, Schulz-Kindermann F, Neumann K, Kruse M, Dinkel A, Kunze S, Balck F, Kroger N, Koch U, Mehnert A (2014) Fear of recurrence and its impact on quality of life in patients with hematological cancers in the course of allogeneic hematopoietic SCT. Bone Marrow Transplant 49(9): 1217-1222. https://doi.org/10.1038/bmt.2014.139

43. Grulke N, Bunjes D, Larbig W, Kachele H, Bailer H (2008) Physicians' prognostic estimates of survival for patients undergoing allogeneic hematopoietic stem cell transplantation. J Psychosom Res 65(1):61-66. https://doi.org/10.1016/j.jpsychores. 2008.01.008

44. Han H, Liu Y, Qin Y, Guo W, Ruan Y, Wu C, Cao Y, He J (2019) Utilization of palliative care for patients undergoing hematopoietic stem cell transplantation during hospitalization: a population-based national study. Am J Hosp Palliat Care 36(10):900-906. https://doi. org/10.1177/1049909119838975

45. Hefner J, Kapp M, Drebinger K, Dannenmann A, Einsele H, Grigoleit GU, Faller H, Csef H, Mielke S (2014) High prevalence of distress in patients after allogeneic hematopoietic SCT: fear of progression is associated with a younger age. Bone Marrow Transplant 49(4):581-584. https://doi.org/10.1038/bmt.2013.228

46. Heinonen H, Volin L, Zevon MA, Uutela A, Barrick C, Ruutu T (2005) Stress among allogeneic bone marrow transplantation patients. Patient Educ Couns 56(1):62-71. https://doi.org/10.1016/j. pec.2003.12.007

47. Loggers ET, LeBlanc TW, El-Jawahri A, Fihn J, Bumpus M, David J, Horak P, Lee SJ (2016) Pretransplantation supportive and palliative care consultation for high-risk hematopoietic cell transplantation patients. Biol Blood Marrow Transplant 22(7):1299-1305. https://doi.org/10.1016/j.bbmt.2016.03.006

48. Scherwath A, Schirmer L, Kruse M, Ernst G, Eder M, Dinkel A, Kunze S, Balck F, Bornhauser M, Ehninger G, Dolan K, Gramatzki M, Kolb HJ, Heussner P, Wilhelm H, Beelen DW, SchulzKindermann F, Zander AR, Koch U, Mehnert A (2013) Cognitive functioning in allogeneic hematopoietic stem cell transplantation recipients and its medical correlates: a prospective multicenter study. Psychooncology 22(7):1509-1516. https://doi.org/10.1002/ pon. 3159

49. Schulz-Kindermann F, Mehnert A, Scherwath A, Schirmer L, Schleimer B, Zander AR, Koch U (2007) Cognitive function in the acute course of allogeneic hematopoietic stem cell transplantation for hematological malignancies. Bone Marrow Transplant 39(12):789-799. https://doi.org/10.1038/sj.bmt.1705663

50. Valkova V, Jircikova J, Trnkova M, Steinerova K, Keslova P, Lanska M, Koristek Z, Raida L, Krejci M, Kruntoradova K, Dolezal T, Benesova K, Cetkovsky P, Trneny M (2016) The quality of life following allogeneic hematopoietic stem cell transplantation - a multicenter retrospective study. Neoplasma 63(5):743-751. https://doi.org/10.4149/neo_2016_511

51. Wang WS, Ma JD, Nelson SH, Revta C, Buckholz GT, Mulroney CM, Roeland EJ (2017) Advance care planning and palliative care integration for patients undergoing hematopoietic stem-cell transplantation. J Oncol Pract 13(9):e721-e728. https://doi.org/10.1200/ JOP.2016.020321

52. Amonoo HL, Massey CN, Freedman ME, El-Jawahri A, Vitagliano HL, Pirl WF, Huffman JC (2019) Psychological considerations in hematopoietic stem cell transplantation. Psychosomatics 60(4): 331-342. https://doi.org/10.1016/j.psym.2019.02.004

53. Bevans M (2010) Health-related quality of life following allogeneic hematopoietic stem cell transplantation. Hematology Am Soc Hematol Educ Program 2010:248-254. https://doi.org/10.1182/ asheducation-2010.1.248
54. Bevans M, El-Jawahri A, Tierney DK, Wiener L, Wood WA, Hoodin F, Kent EE, Jacobsen PB, Lee SJ, Hsieh MM, Denzen EM, Syrjala KL (2017) National Institutes of Health hematopoietic cell transplantation late effects initiative: the patient-centered outcomes working group report. Biol Blood Marrow Transplant 23(4): 538-551. https://doi.org/10.1016/j.bbmt.2016.09.011

55. El-Jawahri A, Nelson AM, Gray TF, Lee SJ, LeBlanc TW (2020) Palliative and end-of-life care for patients with hematologic malignancies. J Clin Oncol 38(9):944-953. https://doi.org/10.1200/JCO. 18.02386

56. Jim HS, Evans B, Jeong JM, Gonzalez BD, Johnston L, Nelson AM, Kesler S, Phillips KM, Barata A, Pidala J, Palesh O (2014) Sleep disruption in hematopoietic cell transplantation recipients: prevalence, severity, and clinical management. Biol Blood Marrow Transplant 20(10):1465-1484. https://doi.org/10.1016/j. bbmt.2014.04.010

57. Mohty B, Mohty M (2011) Long-term complications and side effects after allogeneic hematopoietic stem cell transplantation: an update. Blood Cancer J 1(4):e16. https://doi.org/10.1038/bcj.2011. 14

58. Phillips KM, McGinty HL, Cessna J, Asvat Y, Gonzalez B, Cases MG, Small BJ, Jacobsen PB, Pidala J, Jim HS (2013) A systematic review and meta-analysis of changes in cognitive functioning in adults undergoing hematopoietic cell transplantation. Bone Marrow Transplant 48(10):1350-1357. https://doi.org/10.1038/ bmt.2013.61

59. Pidala J, Anasetti C, Jim H (2009) Quality of life after allogeneic hematopoietic cell transplantation. Blood 114(1):7-19. https://doi. org/10.1182/blood-2008-10-182592

60. Pidala J, Anasetti C, Jim H (2010) Health-related quality of life following haematopoietic cell transplantation: patient education, evaluation and intervention. Br J Haematol 148(3):373-385. https://doi.org/10.1111/j.1365-2141.2009.07992.x

61. Pidala J (2011) Graft-vs-host disease following allogeneic hematopoietic cell transplantation. Cancer Control 18(4):268-276. https:// doi.org/10.1177/107327481101800407

62. Roeland E, Mitchell W, Elia G, Thornberry K, Herman H, Cain J, Atayee R, Bardwell W, von Gunten CF (2010) Symptom control in stem cell transplantation: a multidisciplinary palliative care team approach. Part 2: psychosocial concerns. J Support Oncol 8(4): 179-183

63. Roeland E, Mitchell W, Elia G, Thornberry K, Herman H, Cain J, Atayee R, Bardwell W, von Gunten CF (2010) Symptom control in stem cell transplantation: a multidisciplinary palliative care team approach. Part 1: Physical symptoms. J Support Oncol 8(3):100 116

64. Wulff-Burchfield EM, Jagasia M, Savani BN (2013) Long-term follow-up of informal caregivers after allo-SCT: a systematic review. Bone Marrow Transplant 48(4):469-473. https://doi.org/10. 1038/bmt.2012.123

65. Mosher CE, Redd WH, Rini CM, Burkhalter JE, DuHamel KN (2009) Physical, psychological, and social sequelae following hematopoietic stem cell transplantation: a review of the literature. Psychooncology 18(2):113-127. https://doi.org/10.1002/pon.1399

66. Laudenslager ML, Simoneau TL, Mikulich-Gilbertson SK, Natvig C, Brewer BW, Sannes TS, Kilbourn K, Gutman J, McSweeney P (2019) A randomized control trial of stress management for caregivers of stem cell transplant patients: effect on patient quality of life and caregiver distress. Psychooncology 28(8):1614-1623. https://doi.org/10.1002/pon.5126

67. Vinci C, Pidala J, Lau P, Reblin M, Jim H (2020) A mindfulnessbased intervention for caregivers of allogeneic hematopoietic stem cell transplant patients: Pilot results. Psychooncology 29(5):934 937. https://doi.org/10.1002/pon.5353

68. Etkind SN, Bristowe K, Bailey K, Selman LE, Murtagh FE (2017) How does uncertainty shape patient experience in advanced illness? 
A secondary analysis of qualitative data. Palliat Med 31(2):171180. https://doi.org/10.1177/0269216316647610

69. Hansen BS, Rortveit K, Leiknes I, Morken I, Testad I, Joa I, Severinsson E (2012) Patient experiences of uncertainty - a synthesis to guide nursing practice and research. J Nurs Manag 20(2): 266-277. https://doi.org/10.1111/j.1365-2834.2011.01369.x

70. Mishel MH (1988) Uncertainty in illness. Image J Nurs Sch 20(4): 225-232. https://doi.org/10.1111/j.1547-5069.1988.tb00082.x

71. Kimbell B, Boyd K, Kendall M, Iredale J, Murray SA (2015) Managing uncertainty in advanced liver disease: a qualitative, multiperspective, serial interview study. BMJ Open 5(11): e009241. https://doi.org/10.1136/bmjopen-2015-009241

72. Nanton V, Munday D, Dale J, Mason B, Kendall M, Murray S (2016) The threatened self: considerations of time, place, and uncertainty in advanced illness. Br J Health Psychol 21(2):351-373. https://doi.org/10.1111/bjhp.12172

73. Politi MC, Han PK, Col NF (2007) Communicating the uncertainty of harms and benefits of medical interventions. Med Decis Mak 27(5):681-695. https://doi.org/10.1177/0272989X07307270

74. Lebel S, Ozakinci G, Humphris G, Mutsaers B, Thewes B, Prins J, Dinkel A, Butow P, University of Ottawa Fear of Cancer Recurrence Colloquium a (2016) From normal response to clinical problem: definition and clinical features of fear of cancer recurrence. Support Care Cancer 24(8):3265-3268. https://doi.org/10. 1007/s00520-016-3272-5

75. Mehnert A, Koch U, Sundermann C, Dinkel A (2013) Predictors of fear of recurrence in patients one year after cancer rehabilitation: a prospective study. Acta Oncol 52(6):1102-1109. https://doi.org/10. 3109/0284186X.2013.765063

76. Cherny NI, Coyle N, Foley KM (1994) Suffering in the advanced cancer patient: a definition and taxonomy. J Palliat Care 10(2):5770

77. Neel C, Lo C, Rydall A, Hales S, Rodin G (2015) Determinants of death anxiety in patients with advanced cancer. BMJ Support Palliat Care 5(4):373-380. https://doi.org/10.1136/bmjspcare2012-000420

78. Vollmer TC, Wittmann M, Schweiger C, Hiddemann W (2011) Preoccupation with death as predictor of psychological distress in patients with haematologic malignancies. Eur J Cancer Care (Engl) 20(3):403-411. https://doi.org/10.1111/j.1365-2354.2010.01203.x

79. Grossman CH, Brooker J, Michael N, Kissane D (2018) Death anxiety interventions in patients with advanced cancer: A systematic review. Palliat Med 32(1):172-184. https://doi.org/10.1177/ 0269216317722123

80. Curran L, Sharpe L, MacCann C, Butow P (2020) Testing a model of fear of cancer recurrence or progression: the central role of intrusions, death anxiety and threat appraisal. J Behav Med 43(2): 225-236. https://doi.org/10.1007/s10865-019-00129-x

81. Lebel S, Maheu C, Lefebvre M, Secord S, Courbasson C, Singh M, Jolicoeur L, Benea A, Harris C, Fung MF, Rosberger Z, Catton P (2014) Addressing fear of cancer recurrence among women with cancer: a feasibility and preliminary outcome study. J Cancer Surviv 8(3):485-496. https://doi.org/10.1007/s11764-014-0357-3
82. Sharpe L, Curran L, Butow P, Thewes B (2018) Fear of cancer recurrence and death anxiety. Psychooncology 27(11):2559-2565. https://doi.org/10.1002/pon.4783

83. Fadul NA, El Osta B, Dalal S, Poulter VA, Bruera E (2008) Comparison of symptom burden among patients referred to palliative care with hematologic malignancies versus those with solid tumors. J Palliat Med 11(3):422-427. https://doi.org/10.1089/jpm. 2007.0184

84. Kaiser F, Rudloff LV, Vehling-Kaiser U, Hollburg W, Nauck F, Alt-Epping B (2017) Palliative home care for patients with advanced haematological malignancies-a multicenter survey. Ann Hematol 96(9):1557-1562. https://doi.org/10.1007/s00277-0173045-3

85. LeBlanc TW, Smith JM, Currow DC (2015) Symptom burden of haematological malignancies as death approaches in a community palliative care service: a retrospective cohort study of a consecutive case series. Lancet Haematol 2(8):e334-e338. https://doi.org/10. 1016/S2352-3026(15)00111-8

86. McCaughan D, Roman E, Smith AG, Garry AC, Johnson MJ, Patmore RD, Howard MR, Howell DA (2019) Perspectives of bereaved relatives of patients with haematological malignancies concerning preferred place of care and death: a qualitative study. Palliat Med 33(5):518-530. https://doi.org/10.1177/ 0269216318824525

87. Levine DR, Baker JN, Wolfe J, Lehmann LE, Ullrich C (2017) Strange bedfellows no more: how integrated stem-cell transplantation and palliative care programs can together improve end-of-life care. J Oncol Pract 13(9):569-577. https://doi.org/10.1200/JOP. 2017.021451

88. Tierney DK, Passaglia J, Jenkins P (2014) Palliative care of hematopoietic cell transplant recipients and families. Semin Oncol Nurs 30(4):253-261. https://doi.org/10.1016/j.soncn.2014.08.007

89. El-Jawahri A, LeBlanc TW, Burns LJ, Denzen E, Meyer C, Mau LW, Roeland EJ, Wood WA, Petersdorf E (2018) What do transplant physicians think about palliative care? A national survey study. Cancer 124(23):4556-4566. https://doi.org/10.1002/cncr. 31709

90. LeBlanc TW, El-Jawahri A (2015) When and why should patients with hematologic malignancies see a palliative care specialist? Hematology Am Soc Hematol Educ Program 2015:471-478. https://doi.org/10.1182/asheducation-2015.1.471

91. Moreno-Alonso D, Porta-Sales J, Monforte-Royo C, TrelisNavarro J, Sureda-Balari A, Fernandez De Sevilla-Ribosa A (2018) Palliative care in patients with haematological neoplasms: an integrative systematic review. Palliat Med 32(1):79-105. https:// doi.org/10.1177/0269216317735246

92. Selvaggi KJ, Vick JB, Jessell SA, Lister J, Abrahm JL, Bernacki R (2014) Bridging the gap: a palliative care consultation service in a hematological malignancy-bone marrow transplant unit. J Commun Support Oncol 12(2):50-55. https://doi.org/10.12788/jcso.0015

Publisher's note Springer Nature remains neutral with regard to jurisdictional claims in published maps and institutional affiliations. 